\title{
Ti6Al4V 合金の耐焼付き性に及ぼす酸素拡散処理の影響
}

\author{
高橋恭 佐藤 栄一 \\ 株式会社本田技術研究所二輪開発センター \\ J. Japan Inst. Metals, Vol. 72, No. 12 (2008), pp. 997-1001 \\ Special Issue on Strategy for Ubiquitous Titanium Alloys \\ (C) 2008 The Japan Institute of Metals
}

\section{Influence of Oxygen Diffusion Treatment on Seizure Resistance of Ti6Al4V Alloy}

Kyo Takahashi and Eiichi Sato

Honda R \& D Co. Ltd., Motorcycle R \& D Center, Saitama 351-8555

Typically, titanium does not have good seizure toughness. In general, a surface treatment must be applied if the component is subjected to sliding contact. Various surface treatments, including ion plating, plasma spray, metal plating, etc., are used to increase seizure resistance. This report details a surface modification process using a low cost interstitial element (oxygen) in a standard atmosphere furnace as the surface diffusion element. We investigated changes in the microstructure and mechanical properties in the vicinity of the surface and sliding properties. As a result, we were able to improve seizure resistance by effectively using oxygen for surface modification.

(Received June 3, 2008; Accepted October 2, 2008)

Keywords: titanium, surface treatment, surface hardening, oxygen diffusion, seizure

\section{1. 緒言}

チタン合金は一般構造用材料である鉄鋼材料に対して比強 度に優れていることから, エンジン部品の軽量化に有効な材 料である. そのため, レース用を初めとする高性能エンジン に拉いては，コンロッドやエンジンバルブといった部品にチ タンは多く用いられ, フリクション低減や然費向上などのメ リットをもたらしてきた.

その表面処理には, モリブデン溶射, クロムメッキ, $\mathrm{CrN}$ プレーティング等が用いられているが高価な表面処理が多く なかなか廉価な表面処理が用いられていないのが現状であ る1-3). そしてチタンを機能材料と考える上で習動摩耗性の 問題は避けることのできないものであり，また今後のチタン 材料普及のためには，材料自体のユビキタス化と共に表面処 理のユビキタス化も必要である，そこで本稿ではユビキタス 元素である酸素を用いた酸素拡散処理 (Oxygen Diffusion treatment 以下 OD 処理)を用いての耐焼付き処理としての 効果㧍よび特性変化を報告する.

\section{2. 実 験 方 法}

試料には汎用チタン合金である Ti6Al4V 合金を用いた。 実験に用いたサンプルの化学成分を Table 1 に示す. 各試験 に用いるサンプルは焼鈍素材からの削り出しにより作製し, その一部については表面処理として OD 処理を行った.この $\mathrm{OD}$ 処理は被処理物の表面を有機溶剂による超音波洗浄にて 脱脂洗浄した後, 大気循環炉を用いて加熱することで処理物
Table 1 Chemical compositions of Ti-6Al-4V used in this study.

\begin{tabular}{ccccccc}
\hline $\mathrm{C}$ & $\mathrm{Al}$ & $\mathrm{V}$ & $\mathrm{Fe}$ & $\mathrm{O}$ & $\mathrm{N}$ & $\mathrm{H}$ \\
\hline 0.007 & 6.48 & 4.17 & 0.15 & 0.157 & 0.021 & 0.0011 \\
\hline & & & & & & (mass\%)
\end{tabular}

表面に酸化による硬化層を生成するものである. 加熱炉の雲 囲気管理は特に行わず，873～993 K の各温度にて最大 86.4 ks 保持を行った後, 师冷したものをサンプルとした.

$\mathrm{OD}$ 処理の実施が機械的特性に与える影響の評価は引張試 験, シャルピー衝撃試験, および回転曲げ疲労試験にて行っ た. 引張試験については JIS $14 \mathrm{~A}$ 号試験片を用い, シャル ピー衝撃試験は JIS Z 2242 に準じたノッチ付き試験片を用 い, $n=5$ の平均值とした. 疲労試験は最小断面径 $\phi 8.0$ の定 形試験片にて行っている. 組織観察については樹脂埋め込み サンプルにエメリー紙での湿式研磨およびアルミナ粉でのバ フ研磨を施したのち, フッ酸, 硝酸, 水を $2: 15: 100$ の割 合の混酸にてエッチングしたものを用いた.

表面の硬さ測定には通常のビッカース硬さ計(荷重 $100 \mathrm{~g}$ ) を用いている. また, OD 処理によって得られる断面硬化層 の硬さプロファイル測定には FISCHER 社製の計装化押込 み硬さ計 HM2000 を用いた．本装置はサブミクロン深さの 圧子押し込みによる硬度評価が可能であり，最表面数十ミク ロン範囲の硬度勾配を断面から測定可能である. 押込久荷重 としては最小 $0.4 \mathrm{mN}$ まで対応可能であるが, 今回は測定值 の安定性を考慮し $50 \mathrm{mN}$ の押込久荷重(圧痕寸法 $2 \sim 3 \mathrm{um}$ ) を採用した。OD 処理により得られる表面組織の相同定には $\mathrm{X}$ 線回折装置(リガク製 RINT1400: Cu 管球)を用いた。測 


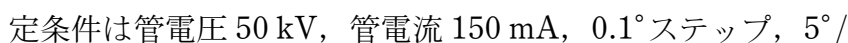
min にて $30 \sim 90^{\circ}$ 範囲で測定し，X 線の単色化には $\mathrm{Ni}$ フィ ルターを用いた。をた OD 処理の摺動特性影響は同和鉱業製 のファビリー試験機にて評価した．試験装置の概略を Fig. 1 に示す。これは回転するピンを 2 個のブロックで挟み込み ながら締め付け荷重を連続的に増加させ，焼付き発生する荷 重を測定することで各種表面処理の耐焼きつき性能を評価す るものである. ピンには面粗度 $R z=3.2 \mu \mathrm{m}$, 外径 $\phi 6.4$ の SCM420 に浸炭焼入れ品を用い, ブロック側を各種条件に て OD 処理した Ti6Al4V 合金とした。ピンの回転速度は $300 \mathrm{rpm}$ であり系全体をエンジンオイル中に浸漬してテスト を行った。

\section{3. 実験結果および考察}

\subsection{OD 処理条件による表面硬さの変化}

873〜993 K, 0〜86.4 ks の条件にて OD 処理を行ったもの の表面硬さ変化を Fig. 2 に示す，表面硬さはスケール層の 上から硬さを測定する為に硬化層だけでなくスケール層の厚 さの影響も受ける事を考慮する必要がある.

高温，長時間処理ほど表面硬さは上昇していく傾向が認め られ，各温度ともに $20 \mathrm{ks}$ 付近から飽和の傾向にある. 硬さ は処理温度が高くなるにつれて高くなっている，それはス ケール層の厚さが増している為だと考えられる，また得られ る表面硬さは時間よりも温度に依存するところが大きく高硬 度皮膜生成のための処理効率としてはより高温側での処理が 望まれる。しかし $973 \mathrm{~K}$ 以上の温度域での処理では被処理 物の自重によるクリープ変形の問題が発生することが多く,
処理時の被処理物保持方法や処理後の冷却方法などに考慮が 必要になることから，今回の研究では $973 \mathrm{~K}$ を標準の処理 条件として各種特性評価を行うこととした．素材の焼鈍条件 は $993 \mathrm{~K}, 2$ 時間であり，本実験では OD 処理温度による内 部組織の変化は特に認められなかった.

\section{$3.20 D$ 処理による表面層の変化}

$\mathrm{OD}$ 処理による表面層の変化として，973 K にて $3.6 \mathrm{ks}$, $18 \mathrm{ks}, 86.4 \mathrm{ks}$ の各時間保持した試料の断面組織を Fig. 3 に，表面近傍の硬さ変化を Fig. 4 示す.

処理時間が長くなるにつれて表面のスケール層が厚くなる とともに，母材表面コントラストの異なる領域も内部に深く 進展していることが確認できる.この領域は Fig. 4 の硬さ 勾配に打ける硬化層領域とほぼ一致しており，母材内に酸素 が拡散することにより固溶強化された相であると考えられ る. また，Fig. 3 中のコントラスト境界は，いずれのサンプ ルにおいてもビッカース硬さで $400 \sim 450$ 程度を示す領域に 一致して抢り，このコントラスト境界を硬化層境界として扱 った. 断面からみた母材最表面部の硬さは保持時間の長さに より若干の差が認められるがほぼ一定值を示し，スケール/ 母材境界部については酸素濃度がほぼ同濃度に達しているこ とが推測される。これによると本合金への酸素固溶により達 成可能な最表面硬さは Hv 700 8 800 と炭素鋼の浸炭焼入れ と同等であり，摺動表面として利用可能なレベルにあると考 えられる ${ }^{4)}$ 。また表面硬さの結果が前述の Fig. 2 と異なるの はFig. 2 の表面硬さはスケール層の上から硬さ測定してい る為である。

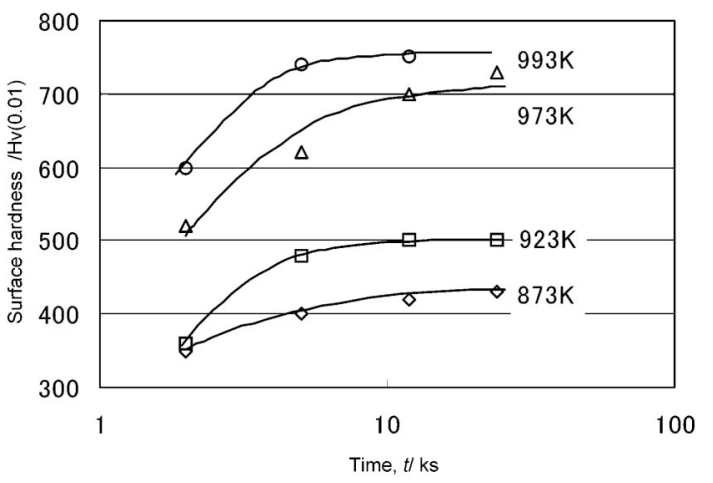

Fig. 2 Surface hardness of OD samples OD treated at various conditions.

Fig. 1 Schematic drawing of faville seizure test.
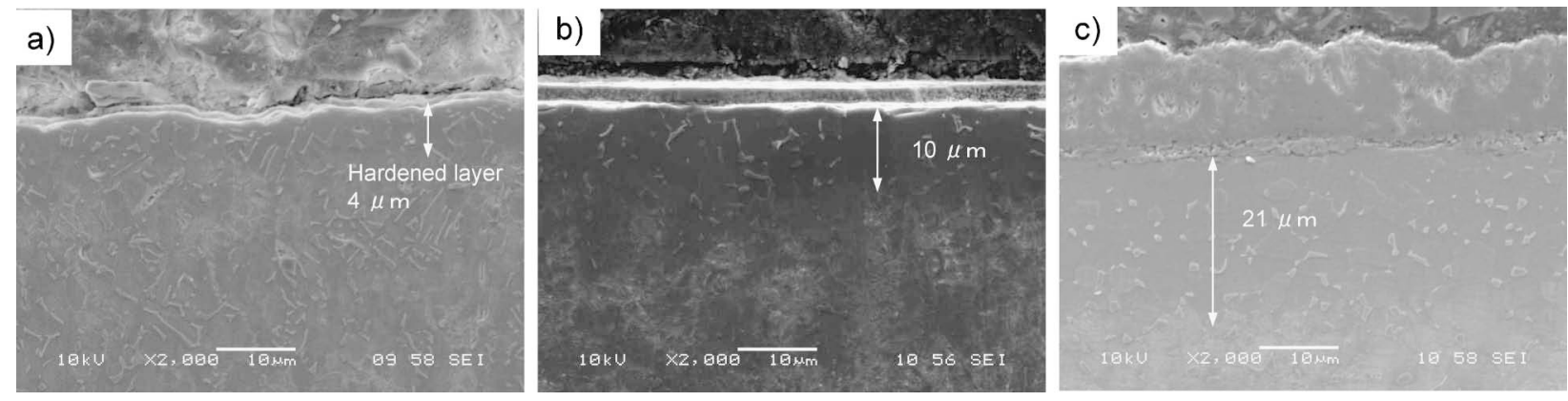

Fig. 3 Secondary electron images of surface layers of specimens OD-treated at $973 \mathrm{~K}$ for (a) $3.6 \mathrm{ks}$, (b) $18 \mathrm{ks}$ and (c) $86.4 \mathrm{ks}$. 
一方，硬化層の深さは長時間処理にても飽和の傾向は見ら

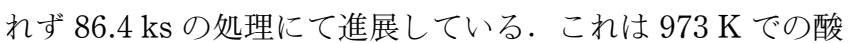
化に抢いては, より長時間の OD 処理によってさらに硬化層 深さを深くすることが可能であることを示唆している.

次に表面 OD 処理層の相変化を確認するために同じく973 $\mathrm{K}$ にて $3.6 \mathrm{ks}, 18 \mathrm{ks}, 86.4 \mathrm{ks}$ 処理したものの表面 X 線回折 の結果を Fig. 5 に示す. $3.6 \mathrm{ks}$ より $18 \mathrm{ks}, 86.4 \mathrm{ks}$ と $\mathrm{TiO}_{2}$ のピーク強さが徐々に大きくなっていくのが確認される. ま た，(0002) $\alpha$ のピークは $\mathrm{TiO}_{2}$ が成長すると共に小さくなり 低角側に移動している。これは $\alpha$ への酸素固溶による格子 歪の発生を示唆していると考えられる.

$\mathrm{OD}$ 処理前のデータと比較すると $\alpha$ 相のピークが大きくな ると共に, 初期にみられた $(110) \beta$ 相のピークが消隇してい るが，これは $\alpha$ 安定化元素である酸素の固溶によって $\alpha$ 相/ $\beta$ 相の比が変化し表面近傍が内部に対して $\alpha$ リッチになって いるためと考えられる.

\section{3 機械的特性}

$973 \mathrm{~K}, 18 \mathrm{ks} \mathrm{OD}$ 処理による静的機械特性の変化を Table 2 に示す.

強度, 伸び, 衝撃エネルギー共に, OD 処理による特性の

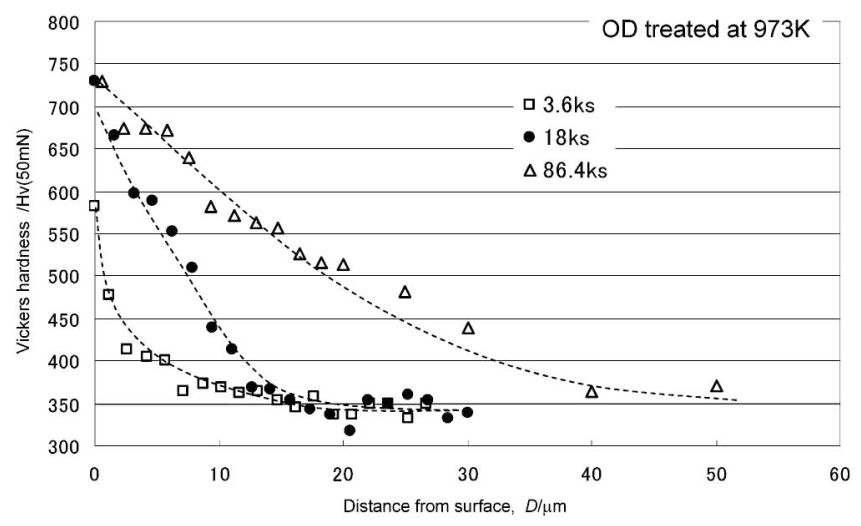

Fig. 4 Change of Vickers hardness with increase of distance from surface.

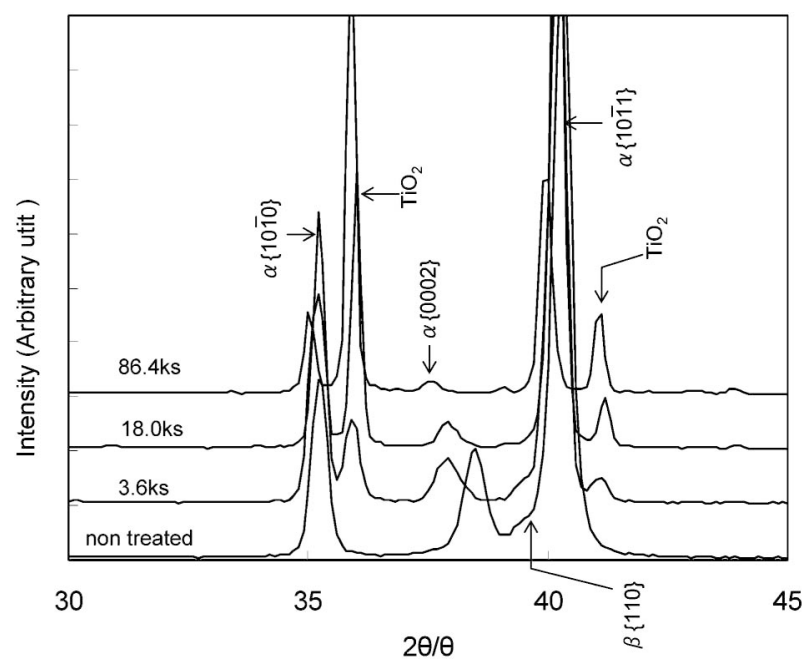

Fig. 5 X-ray diffraction patterns of OD-treated specimens.
変化はほとんど認められず，処理による静的機械特性への影 響はみられなかった。これは OD 処理による生成層であるス ケール層と硬化層を合わせても試料表面近傍数十 $\mu \mathrm{m}$ の極狭 い領域であり，マクロ的な試験片の機械特性への影響が現れ なかったことによると考えられる.これは OD 処理による最 表面の酸素の影響が静的強度には影響しない事が判った. 次 に動的な機械特性として回転曲げ疲労試験の結果を Fig. 6 に示す.

OD 処理により $10^{7}$ 回疲労強度で約 $30 \%$ の低下がみられ る. 疲労強度は静的な引張強度に対して切り欠きや残留応力 による影響を受け易いと考えられるが，この原因としては， 本試験に用いた試験片は前述の通り, OD 処理後炉冷により 作成している為, 残留応力によるものとは考え難く酸化処理 により硬化層の勒性が低下し切り欠きに対する感受性が高く なったと推定する.

Table 2 Mechanical properties.

\begin{tabular}{ccccc}
\hline & TS (MPa) & $\begin{array}{c}0.2 \% \mathrm{YS} \\
(\mathrm{MPa})\end{array}$ & El. (\%) & $\begin{array}{c}\text { Absorbed } \\
\text { energy }(\mathrm{J})\end{array}$ \\
\hline not OD-treated & 1088 & 1019 & 17.0 & 40.7 \\
\hline $\begin{array}{c}\text { OD-treated } \\
(973 \mathrm{~K}, 18 \mathrm{ksec})\end{array}$ & 1058 & 1009 & 16.5 & 40.3 \\
\hline
\end{tabular}

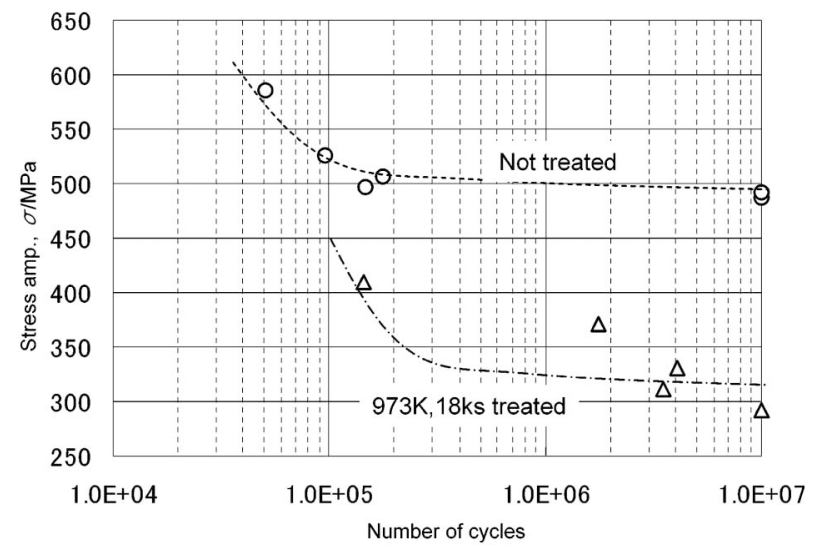

Fig. 6 Rotation bending fatigue test at R.T.

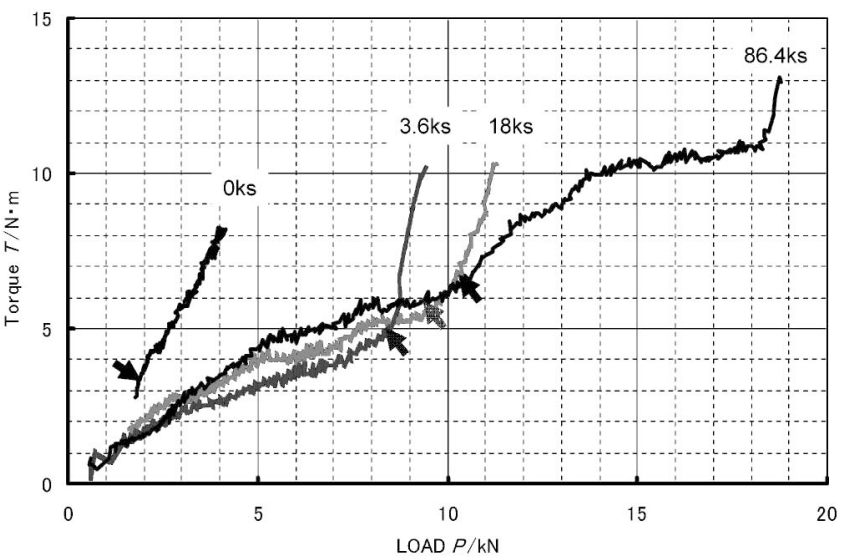

Fig. 7 Relationships between applied load and torque in non OD-treated and various OD-treated specimen. (Bold arrows means seizure point.) 


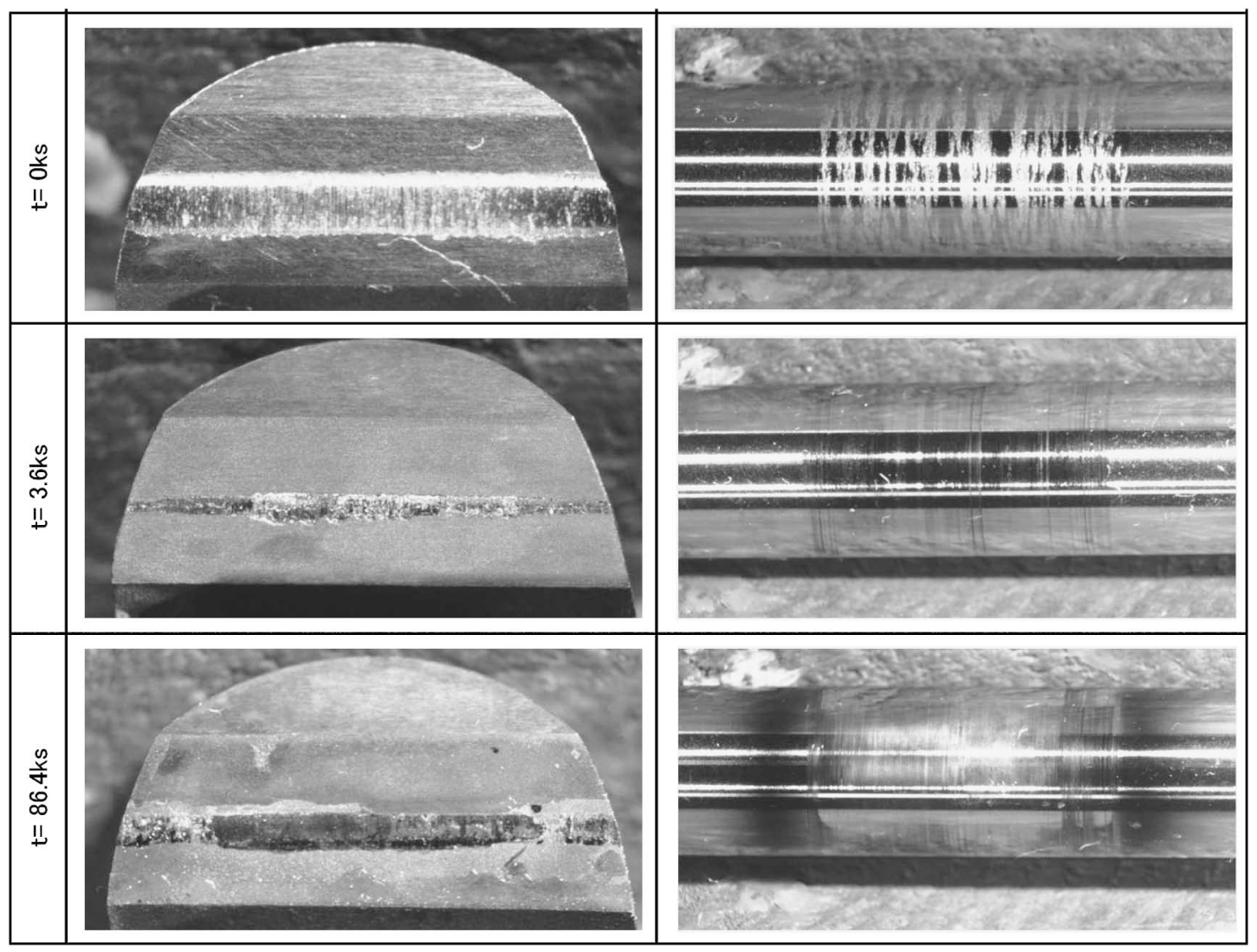

Fig. 8 Appearances of surfaces of specimens after faville seizure tests. (Left) samples of block: Ti-6Al-4V OD treated at $973 \mathrm{~K}$ for $0 \mathrm{ks}$ (non-treated), $3.6 \mathrm{ks}$ and $86.4 \mathrm{ks}$. (Right) samples of pin: SCM420 carbrized.

\section{4 摺動特性}

OD 処理無材，および $973 \mathrm{~K} \mathrm{OD}$ 処理材について，SCM 浸炭相手の焼付き試験を行った結果を Fig. 7 に示す。図中 にて荷重増に伴って急激にトルクが上昇する荷重(図中个に て指示)を焼付き荷重として判断している。 また Fig. 8 には それぞれに試験終了後のテストサンプルの表面状態を示す.

無処理材は試験開始直後の荷重 $200 \mathrm{kgf}$ 以下の領域で既に 焼付きを生じており，浸炭側試験片表面にはチタンの激しい 凝着が認められる。それに対し OD 処理品での焼付き発生荷 重は, 短時間処理の $3.6 \mathrm{ks}$ 処理品においてもその 4 倍の $800 \mathrm{kgf}$ 以上であり，無処理品に対して大きな耐焼付き性の 向上が認められる. $18 \mathrm{ks}$ ，打よび $86.4 \mathrm{ks}$ の長時間処理品 についても焼付き発生荷重は $3.6 \mathrm{ks}$ 処理品とほぼ同等であ り，時間の長時間化は耐焼付き性向上に与える効果が小さ い. 前述した硬さプロファイルの結果と合わせて考えると, 習動時の耐焼付き性を主として支配しているのは硬化層の表 面硬度であり，長時間 OD 処理による硬化層深さアップは耐 焼き付き性に与える効果が小さいものと考えられる. 連続的 な硬化層の摩耗減肉のような摩耗形態によっては硬化層厚さ が摩耗寿命向上に影響すると考えられるが，チタンの摺動に おいては摩耗の初期段階で摺動表面のミクロ的な塑性変形が おこり, 内部の新生面が摺動表面に露出した時点で急激に凝 着摩耗が進行する傾向にあり，最表面の塑性変形に対する耐 性，すなわち最表面の硬さが耐焼付特性を決定しているもの
と考えられる.

また $3.6 \mathrm{ks}, 18 \mathrm{ks}$ 処理材については, 焼付き発生後に試 験トルクが急激に上昇するのに対し， $86.4 \mathrm{ks}$ 処理材につい ては焼付き発生後も比較的緩やかなトルクの上昇が続き, 焼 付き発生後の凝着ダメージが比較的小さい結果がえられた。 この $86.4 \mathrm{ks}$ 処理品の試験終了後の試験片を観察すると, 摺 動部周辺のスケール層が広い範囲で剥離して抢り, 更に剥離 した表面スケールが粉末状になって凝着部周辺に付着してい るのが確認された。これは他の試験片には認められない特長 であり，焼付き発生部の凝着ダメージ低減に対し，粉末状の 剥離したスケールが影響したものと考えられる。これは固体 潤滑材の特性である剪断破壊され易い特性と, 酸化チタンの スケール層が微細な粉末になる状況が似ている事で同じ様な 作用を起こしたと考えている5).

Fig. 3 の表面状態を見れば $86.4 \mathrm{ks}$ の表面が粗くなってい るのが判る.その結果トルクの違いは表面粗さに起因してお り，焼付き荷重は表面硬さに起因していると思われる.

\section{4. 結言}

酸素による表面処理は酸素の侵入により表面が硬化し，硬 化の程度は時間と温度の関数に比例する. 硬化表面処理はチ タン合金の焼付き特性を向上させる結果が得られた。チタン の酸化拡散処理は表面の酸素の拡散により表面硬度上昇に伴 う焼付き特性の向上を示す。 
従来チタンに対しての酸化処理は機能表面処理としての役 割は少なく，そのほとんどが外観の為に使われてきた。しか しながらユビキタス元素である酸素の拡散をコントロールす ることで従来チタンに対して弱点であった耐焼付き特性を得 ることが出来た.
文献

1) Wataru Urushihara: Titanium Japan 55(2007) 207-211.

2) Hideki Fujii, Kazuhiro Takahashi and Yoshito Yamashita: Nippon Steel technical review 378(2003) 62-67.

3) Yasuaki Sugisaki and Hiroshi Sato: Titanium Zirconium 39 (1991) 191-199.

4) Takeshi Naito: Actual of carburized quench, (Nikkan Kogyo Shimbun, Tokyo, 1979) pp. 60-62.

5) Yuji Enomoto: New material of Tribology, (Japanese Society of Tribologists, Tokyo, 1991) p. 272. 